\section{Confirmation of association of the REL locus with rheumatoid arthritis susceptibility in the UK population}

Genome-wide association studies (GWAS) have contributed to the identification of at least 14 rheumatoid arthritis (RA) susceptibility loci. ${ }^{1}$ One of the first RA GWAS included 1522 cases and 1850 controls from the USA/Sweden and identified TRAF1/C5 as a novel RA locus. ${ }^{2}$ This GWAS was recently repeated after including an additional 1550 cases and 3310 controls from the USA and restricting analysis to US subjects. ${ }^{3}$ In the expanded sample, two novel single nucleotide polymorphisms (SNP) mapping to the REL locus showed association with RA. REL encodes c-Rel, a member of the nuclear factor kappa B family of transcription factors and one of the associated SNP (rs13031237) maps to an intron of this gene. The association was validated in an independent sample of 2604 RA cases and 2882 controls from the USA/Canada, with strong evidence for association in the combined samples ( $r$ 13031237, $\left.p=3.1 \times 10^{-14}\right)$. We aimed to test the association of the same variants with RA in a large UK casecontrol sample.

White patients with RA were recruited from six centres across the UK, with ethical committee approval (MREC 99/8/84) and after providing informed consent. ${ }^{45}$ Genotyping was performed using Sequenom, and only samples and SNP exceeding 90\% success rate were included in the subsequent analysis. Genotype frequencies were compared between cases and controls using the trend test implemented in PLINK. ${ }^{6}$

DNA samples from 3962 RA cases and 3531 controls were available for testing, and the clinical characteristics have been described previously. ${ }^{4}$ The two SNP, rs13031237 and rs13017599, strongly associated with RA in the previous US/ Canadian study were genotyped in the UK samples and both SNP showed strong evidence for association, with no deviation from Hardy-Weinberg expectations (table 1). In the previous study, the subjects investigated were overwhelmingly positive for autoantibodies. ${ }^{3}$ We, therefore, undertook subgroup analysis in autoantibody-positive groups. The strength of association was stronger in anticyclic citrullinated peptide antibody positive, rheumatoid factor-positive and autoantibody-positive subgroups compared with the overall group. A meta-analysis of data from the previous US/Canadian sample and the current UK group was undertaken and increased the strength of evidence for association to $1.7 \times 10^{-17}$ (figure 1 ).

In this large sample, we provide confirmation of association of the REL locus with RA in a UK population. The associated markers map $28.5 \mathrm{~kb}$ apart on chromosome $2 \mathrm{p}$, are in almost complete linkage disequilibrium $\left(r^{2}=0.97, D^{\prime}=1\right)$ and, in logistic regression models, it was not possible to determine which was driving the association. Rs13017599 is a synonymous substitution (asparagine) within the ribosomal protein S12 pseudo gene 3 (RPS12P3), which is not an obvious candidate RA gene. Rs13031237 maps to an intron of REL, which is a stronger candidate RA gene because, first, it encodes a component of the nuclear factor kappa B signalling pathway and, second, c-Rel-deficient mice are resistant to the induction of collagen-induced arthritis, suggesting a crucial role for $\mathrm{c}-\mathrm{Rel}$ in the development of systemic autoimmunity. ${ }^{7}$ There are no other confirmed online under the BMJ Journals unlocked scheme, see http:// ard.bmi.com/info/unlocked.dt
Table 1 Genotype counts and frequencies for SNP mapping to chromosome $2 p$ in UK RA cases and controls and association of SNP in subgroups stratified by autoantibody status

\begin{tabular}{|c|c|c|}
\hline & rs13031237 & rs13017599 \\
\hline \multicolumn{3}{|l|}{ Case, $\mathrm{n}(\%)$} \\
\hline $2 / 2$ & $508(14.9)$ & $507(14.8)$ \\
\hline $1 / 2$ & $1674(49.0)$ & $1672(48.9)$ \\
\hline $1 / 1$ & $1234(36.1)$ & $1239(36.2)$ \\
\hline \multicolumn{3}{|l|}{ Control, n (\%) } \\
\hline $2 / 2$ & $350(12.7)$ & $352(12.8)$ \\
\hline $1 / 2$ & $1271(46.2)$ & $1270(46.1)$ \\
\hline $1 / 1$ & $1128(41.1)$ & $1133(41.1)$ \\
\hline \multicolumn{3}{|c|}{ Case-control comparison } \\
\hline $\mathrm{p}$-Trend & $5.26 \times 10^{-5}$ & $6.96 \times 10^{-5}$ \\
\hline Allelic OR (95\% Cl) & 1.16 (1.08 to 1.25$)$ & $1.16(1.08$ to 1.25$)$ \\
\hline \multicolumn{3}{|c|}{$R F+(n=2370)$ vs controls $(n=2758)$} \\
\hline $\mathrm{p}$-Trend & $2.83 \mathrm{E}-06$ & $3.91 \mathrm{E}-06$ \\
\hline Allelic OR (95\% Cl) & 1.21 (1.12 to 1.31$)$ & $1.21(1.11$ to 1.31$)$ \\
\hline \multicolumn{3}{|c|}{$R F-(n=784)$ vs controls $(n=2758)$} \\
\hline $\mathrm{p}$-Trend & 0.37 & 0.42 \\
\hline Allelic OR (95\% Cl) & $1.06(0.94$ to 1.19$)$ & 1.05 (0.93 to 1.18$)$ \\
\hline \multicolumn{3}{|c|}{ Anti-CCP $+(n=1184)$ vs controls $(n=2758)$} \\
\hline $\mathrm{p}$-Trend & $2.12 \mathrm{E}-05$ & $2.67 \mathrm{E}-05$ \\
\hline Allelic OR (95\% Cl) & $1.24(1.12$ to 1.37$)$ & $1.23(1.12$ to 1.36$)$ \\
\hline \multicolumn{3}{|c|}{ Anti-CCP $-(n=433)$ vs controls $(n=2758)$} \\
\hline $\mathrm{p}$-Trend & 0.34 & 0.41 \\
\hline Allelic OR (95\% Cl) & 0.93 (0.8 to 1.08$)$ & 0.94 (0.81 to 1.09$)$ \\
\hline \multicolumn{3}{|c|}{ Auto-antibody $+(n=2593)$ vs controls $(n=2758)$} \\
\hline $\mathrm{p}$-Trend & $7.71 \times 10^{-7}$ & $1.01 \times 10^{-6}$ \\
\hline Allelic OR (95\% Cl) & 1.22 (1.12 to 1.31$)$ & $1.21(1.12$ to 1.31$)$ \\
\hline
\end{tabular}

1, major allele; 2, minor allele; Anti-CCP+, anti-cyclic citrullinated peptide antibody positive; Anti-CCP-, anticyclic citrullinated peptide antibody negative; Autoantibody +, positive for either rheumatoid factor or anticyclic citrullinated peptide antibodies; $\mathrm{OR}$, odds ratio; $\mathrm{RA}$, rheumatoid arthritis; $\mathrm{RF}+$, rheumatoid factor positive; $\mathrm{RF}-$, rheumatoid factor negative; SNP, single nucleotide polymorphism.

\section{rs13031237}

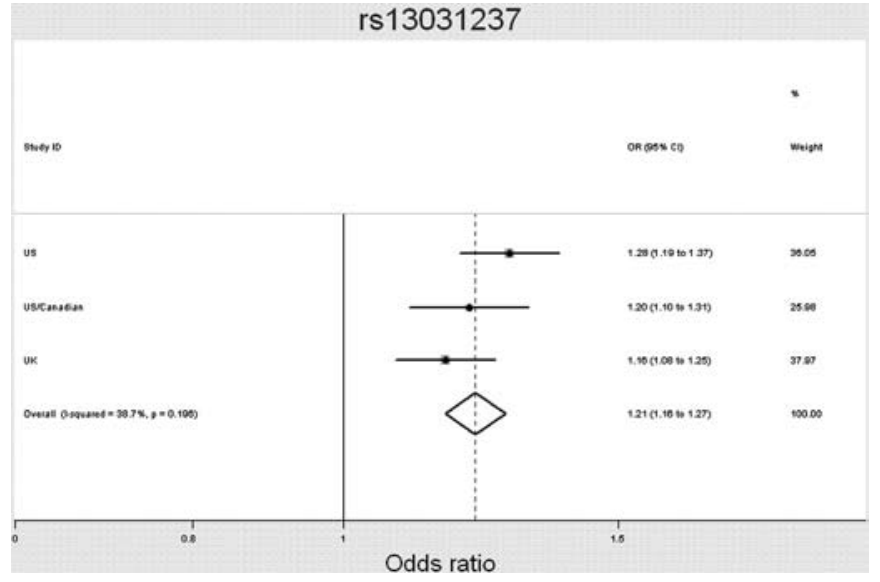

Figure 1 Meta-analysis of current UK data with previous data. US and US/Canadian allele counts from Gregersen et al. ${ }^{3}$ Combined $\mathrm{p}$ value $=1.53 \times 10^{-17}$. OR, odds ratio.

genes within the linkage disequilibrium block defined by SNP with $\mathrm{r}^{2}>0.5$ with either of the SNP tested.

Interestingly, many of the RA loci identified, like the one confirmed here, show stronger effects in autoantibody-positive subgroups, suggesting that autoantibody positive RA may have different underlying pathogenic mechanisms underpinned by 
different genetic loci compared with autoantibody-negative disease. However, it should be noted that the number of autoantibody-negative samples included in studies is often quite small.

In summary, we provide confirmatory support for the association of the REL locus with RA. Fine mapping and functional studies will be required to identify the causal variant(s) and inform our understanding of how these variants influence the pathogenesis of RA.

\section{Stephen Eyre, ${ }^{1}$ Anne Hinks, ${ }^{1}$ Edward Flynn, ${ }^{1}$ Paul Martin, ${ }^{1}$ Anthony G Wilson, ${ }^{2}$ James R Maxwell, ${ }^{2}$ Ann W Morgan, ${ }^{3}$ Paul Emery, ${ }^{3}$ Sophia Steer, ${ }^{4}$ Lynne J Hocking, ${ }^{5}$ David M Reid, ${ }^{5}$ Pille Harrison, ${ }^{6}$ Paul Wordsworth, ${ }^{6}$ Wendy Thomson, ${ }^{1}$ Jane Worthington, ${ }^{1}$ Anne Barton'}

'arc-Epidemiology Unit, Manchester Academy of Health Sciences, The University of Manchester, Manchester, UK

${ }^{2}$ School of Medicine and Biomedical Sciences, Sheffield University, Sheffield, UK ${ }^{3}$ NIHR-Leeds Musculoskeletal Biomedical Research Unit, Leeds Institute of Molecular Medicine, University of Leeds, Leeds, UK

${ }^{4}$ Clinical and Academic Rheumatology Department, Kings College Hospital NHS Foundation Trust, London, UK

${ }^{5}$ Musculoskeletal and Genetics Section, Division of Applied Medicine, University of Aberdeen, Aberdeen, UK

${ }^{6}$ University of Oxford Institute of Musculoskeletal Sciences, Botnar Research Centre, Oxford, UK

Correspondence to Dr Anne Barton, arc-Epidemiology Unit, Stopford Building, Manchester Academy of Health Sciences, The University of Manchester, Oxford Road, Manchester M13 9PT, UK; anne.barton@manchester.ac.uk
Acknowledgements The authors would like to thank the Arthritis Research Campaign for their support (arc grant reference no 17552). They also acknowledge support from the NIHR Manchester Biomedical Research Centre, the NIHR Oxford Musculoskeletal Biomedical Research Centre and the NIHR Leeds Musculoskeletal Biomedical Research Unit.

Ethics approval This study was conducted with the approval of the North West Regional Ethics Committee (MREC 99/8/84).

Provenance and peer review Not commissioned; externally peer reviewed.

Patient consent Obtained.

Accepted 8 November 2009

Ann Rheum Dis 2010;69:1572-1573. doi:10.1136/ard.2009.122887

\section{REFERENCES}

1. Barton A, Worthington J. Genetic susceptibility to rheumatoid arthritis: an emerging picture. Arthritis Rheum 2009;61:1441-6.

2. Plenge RM, Seielstad M, Padyukov L, et al. TRAF1-C5 as a risk locus for rheumatoid arthritis—a genomewide study. N Engl J Med 2007;357:1199-209.

3. Gregersen PK, Amos Cl, Lee AT, et al. REL, encoding a member of the NF-kappa B family of transcription factors, is a newly defined risk locus for rheumatoid arthritis. Nat Genet 2009:41:820-3.

4. Thomson W, Barton A, Ke X, et al. Rheumatoid arthritis association at 6q23. Nat Genet 2007;39:1431-3.

5. Barton A, Thomson W, Ke X, et al. Rheumatoid arthritis susceptibility loci at chromosomes 10p15, 12q13 and 22q13. Nat Genet 2008;40:1156-9.

6. Purcell S, Neale B, Todd-Brown K, et al. PLINK: a tool set for wholegenome association and population-based linkage analyses. Am J Hum Genet 2007:81:559-75.

7. Campbell IK, Gerondakis S, O'Donnell K, et al. Distinct roles for the NF-kappaB1 (p50) and c-Rel transcription factors in inflammatory arthritis. J Clin Invest 2000;105:1799-806. 


\section{Corrections}

The department of one of the authors who co-authored all of the below papers has found that the affiliations were not correct. The correct affiliations for Professor P Emery, for all of the below articles, are: ${ }^{1}$ Section of Musculoskeletal Disease, Leeds Institute of Molecular Medicine, University of Leeds; ${ }^{2}$ NIHR Leeds Musculoskeletal Biomedical Research Unit, Leeds Teaching Hospitals Trust, Leeds, UK.

1. Keystone E, Emery P, Peterfy CG, et al. Rituximab inhibits structural joint damage in patients with rheumatoid arthritis with an inadequate response to tumour necrosis factor inhibitor therapies. Ann Rheum Dis 2009;68:216-21.

2. Doward LC, McKenna SP, Whalley D, et al. The development of the L-OoL: a quality-of-life instrument specific to systemic lupus erythematosus. Ann Rheum Dis 2009;68:196-200.

3. Potter C, Hyrich KL, Tracey A, et al. Association of rheumatoid factor and anticyclic citrullinated peptide positivity, but not carriage of shared epitope or PTPN22 susceptibility variants, with anti-TNF response in RA. Ann Rheum Dis 2009;68:69-74.

4. Smolen JS, Han C, van der Heijde DM, et al.; Active-Controlled Study of Patients Receiving Infliximab for the Treatment of Rheumatoid Arthritis of Early Onset (ASPIRE) Study Group. Radiographic changes in rheumatoid arthritis patients attaining different disease activity states with methotrexate monotherapy and infliximab plus methotrexate: the impacts of remission and tumour necrosis factor blockade. Ann Rheum Dis 2009;68:823-7.

5. Buch MH, Boyle DL, Rosengren S, et al. Mode of action of abatacept in rheumatoid arthritis patients having failed tumour necrosis factor blockade: a histological, gene expression and dynamic magnetic resonance imaging pilot study. Ann Rheum Dis 2009;68:1220-7.

6. Emery P, Van Vollenhoven R, Ostergaard M, et al. Guidelines for initiation of antitumour necrosis factor therapy in rheumatoid arthritis: similarities and differences across Europe. Ann Rheum Dis 2009;68:456-9.

7. Bejarano V, Conaghan PG, Proudman SM, et al. Long-term efficacy and toxicity of ciclosporin A in combination with methotrexate in poor prognosis rheumatoid arthritis Ann Rheum Dis 2009;68:761-3.

8. Rudwaleit M, Landewé R, van der Heijde D, et al. The development of Assessment of SpondyloArthritis international Society classification criteria for axial spondyloarthritis (part I): classification of paper patients by expert opinion including uncertainty appraisal. Ann Rheum Dis 2009;68:770-6.

9. Bennett AN, Marzo-Ortega H, Emery P, et al.; Leeds Spondyloarthropathy Group. Diagnosing axial spondyloarthropathy. The new Assessment in SpondyloArthritis international Society criteria: MRI entering centre stage. Ann Rheum Dis 2009;68:765-7.

10. Marzo-Ortega H, McGonagle D, O'Connor P, et al. Baseline and 1-year magnetic resonance imaging of the sacroiliac joint and lumbar spine in very early inflammatory back pain. Relationship between symptoms, HLA-B27 and disease extent and persistence. Ann Rheum Dis 2009;68:1721-7.

11. Gilworth G, Emery P, Gossec L, et al. Adaptation and cross-cultural validation of the rheumatoid arthritis work instability scale (RA-WIS). Ann Rheum Dis 2009;68:1686-90.

12. Gilworth G, Emery P, Gossec L, et al. Adaptation and cross-cultural validation of the RA-WIS (Work Instability Scale). Ann Rheum Dis 2009;68:1686-90.

13. Jarrett SJ, Sivera F, Cawkwell LS, et al. MRI and clinical findings in patients with ankylosing spondylitis eligible for anti-tumour necrosis factor therapy after a short course of etoricoxib. Ann Rheum Dis 2009;68:1466-9.

14. Haugeberg G, Conaghan PG, Quinn $\mathrm{M}$, et al. Bone loss in patients with active early rheumatoid arthritis: infliximab and methotrexate compared with methotrexate treatment alone. Explorative analysis from a 12-month randomised, double-blind, placebo-controlled study. Ann Rheum Dis 2009;68:1898-901.

15. Genovese MC, Breedveld FC, Emery P, et al. Safety of biological therapies following rituximab treatment in rheumatoid arthritis patients. Ann Rheum Dis 2009;68:1894-7

16. Kekow J, Moots RJ, Emery P, et al. Patient-reported outcomes improve with etanercept plus methotrexate in active early rheumatoid arthritis and the improvement is strongly associated with remission: the COMET trial. Ann Rheum Dis 2010;69:222-5

17. Furst DE, Keystone EC, Fleischmann R, et al. Updated consensus statement on biological agents for the treatment of rheumatic diseases, 2009. Ann Rheum Dis 2010;69(Suppl 1):i2-29.

18. Freeston JE, Wakefield RJ, Conaghan PG, et al. A diagnostic algorithm for persistence of very early inflammatory arthritis: the utility of power Doppler ultrasound when added to conventional assessment tools. Ann Rheum Dis 2010;69:417-9.

19. Jones $\mathbf{E}$, Churchman SM, English A, et al. Mesenchymal stem cells in rheumatoid synovium: enumeration and functional assessment in relation to synovial inflammation level. Ann Rheum Dis 2010;69:450-7.

20. Alten RE, Zerbini C, Jeka S, et al. Efficacy and safety of pamapimod in patients with active rheumatoid arthritis receiving stable methotrexate therapy. Ann Rheum Dis 2010;69:364-7.
21. Machold KP, Landewé R, Smolen JS, et al. The Stop Arthritis Very Early (SAVE) trial, an international multicentre, randomised, double-blind, placebo-controlled trial on glucocorticoids in very early arthritis. Ann Rheum Dis 2010;69:495-502.

22. Schoels M, Knevel R, Aletaha D, et al. Evidence for treating rheumatoid arthritis to target: results of a systematic literature search. Ann Rheum Dis 2010;69:638-43.

23. Smolen JS, Aletaha D, Bijlsma JW, et al.; T2T Expert Committee. Treating rheumatoid arthritis to target: recommendations of an international task force. Ann Rheum Dis 2010;69:631-7.

24. Burr ML, Naseem H, Hinks A, et al.; BIRAC Consortium; YEAR Consortium. PADI4 genotype is not associated with rheumatoid arthritis in a large UK Caucasian population. Ann Rheum Dis 2010;69:666-70.

25. Emery $\mathbf{P}$, Durez P, Dougados $\mathrm{M}$, et al. Impact of T-cell costimulation modulation in patients with undifferentiated inflammatory arthritis or very early rheumatoid arthritis: a clinical and imaging study of abatacept (the ADJUST trial). Ann Rheum Dis 2010;69:510-16.

26. Bennett AN, Rehman A, Hensor EM, et al. The fatty Romanus lesion: a noninflammatory spinal MRI lesion specific for axial spondyloarthropathy. Ann Rheum Dis 2010;69:891-4.

27. Nam JL, Winthrop KL, van Vollenhoven RF, et al. Current evidence for the management of rheumatoid arthritis with biological disease-modifying antirheumatic drugs: a systematic literature review informing the EULAR recommendations for the management of RA. Ann Rheum Dis 2010;69:976-86.

28. Smolen JS, Landewé R, Breedveld FC, et al. EULAR recommendations for the management of rheumatoid arthritis with synthetic and biological disease-modifying antirheumatic drugs. Ann Rheum Dis 2010;69:964-75.

29. Tan RJ, Gibbons LJ, Potter C, et al.; BRAGGSS. Investigation of rheumatoid arthritis susceptibility genes identifies association of AFF3 and CD226 variants with response to anti-tumour necrosis factor treatment. Ann Rheum Dis 2010;69:1029-35.

30. Robinson JI, Barrett JH, Taylor JC, et al.; YEAR Consortium; BRAGGSS. Dissection of the FCGR3A association with RA: increased association in men and with autoantibody positive disease. Ann Rheum Dis 2010;69:1054-7.

31. Cohen SB, Keystone E, Genovese MC, et al. Continued inhibition of structural damage over 2 years in patients with rheumatoid arthritis treated with rituximab in combination with methotrexate. Ann Rheum Dis 2010;69:1158-61.

32. Haugeberg G, Bennett AN, McGonagle D, et al. Bone loss in very early inflammatory back pain in undifferentiated spondyloarthropathy: a 1-year observational study. Ann Rheum Dis 2010;69:1364-6.

33. Schoels M, Aletaha D, Smolen JS, et al. Follow-up standards and treatment targets in rheumatoid arthritis: results of a questionnaire at the EULAR 2008. Ann Rheum Dis 2010;69:575-8

34. Eyre S, Flynn E, Martin P, et al. No evidence for association of the KLF12 gene with rheumatoid arthritis in a large UK cohort. Ann Rheum Dis 2010;69:1407-8.

35. Eyre S, Hinks A, Flynn E, et al. Confirmation of association of the REL locus with rheumatoid arthritis susceptibility in the UK population. Ann Rheum Dis 2010;69:1572-3

36. Orozco G, Eyre S, Hinks A, et al.; Wellcome Trust Case Control consortium YEAR Consortium. Association of CD40 with rheumatoid arthritis confirmed in a large UK case-control study. Ann Rheum Dis 2010;69:813-16.

37. Emery $\mathbf{P}$, Durez P, Dougados $M$, et al. Impact of T-cell costimulation modulation in patients with undifferentiated inflammatory arthritis or very early rheumatoid arthritis: a clinical and imaging study of abatacept (the ADJUST trial). Ann Rheum Dis 2010;69:510-16

38. Saleem B, Keen $\mathrm{H}$, Goeb V, et al. Patients with RA in remission on TNF blockers: when and in whom can TNF blocker therapy be stopped? Ann Rheum Dis 2010;69:1636-42.

39. Barkham N, Coates LC, Keen H, et al. Double-blind placebo-controlled trial of etanercept in the prevention of work disability in ankylosing spondylitis. Ann Rheum Dis 2010;69:1926-8.

40. Emery P, Deodhar A, Rigby WF, et al. Efficacy and safety of different doses and retreatment of rituximab: a randomised, placebo-controlled trial in patients who are biological naive with active rheumatoid arthritis and an inadequate response to methotrexate (Study Evaluating Rituximab's Efficacy in MTX iNadequate rEsponders (SERENE)). Ann Rheum Dis 2010;69:1629-35.

41. Dixon WG, Hyrich KL, Watson KD, et al.; BSRBR Control Centre Consortium; British Society for Rheumatology Biologics Register. Influence of anti-TNF therapy on mortality in patients with rheumatoid arthritis-associated interstitial lung disease: results from the British Society for Rheumatology Biologics Register. Ann Rheum Dis 2010;69:1086-91. 